Institute for Research on Poverty

Discussion Paper no. 1014-93

\title{
The Education and Labor Market Outcomes of Adolescent Fathers
}

\author{
Maureen A. Pirog-Good \\ Visiting Scholar \\ Institute for Research on Poverty \\ University of Wisconsin-Madison \\ Associate Professor \\ School of Public and Environmental Affairs \\ Indiana University
}

August 1993

This research was completed with the assistance of Sabine Rieble and Kevin Condit and was funded by the Office of Adolescent Pregnancy and Parenting, U.S. Department of Health and Human Services. 


\begin{abstract}
The author examines the educational and labor market outcomes of young men in the United States, with a particular emphasis on adolescent fathers. She finds that men who were teen fathers complete fewer years of education and are less likely to finish high school than men who were not teen fathers. These educational deficits persist even after family and personal characteristics are taken into account. Teen fathers enter the labor market earlier and initially earn more money than other men; by the time teen fathers reach their mid-twenties, they earn less. Somewhat encouragingly, the long-term earnings deficit of teen fathers disappears after controlling for personal and family background. This implies that teen fathers are as capable as other young men from similar backgrounds of providing for their children. Data are from the National Longitudinal Survey of Labor Market Participation-Youth Cohort.
\end{abstract}




\section{The Education and Labor Market Outcomes of Adolescent Fathers}

\section{INTRODUCTION}

This article examines the educational and labor market outcomes of young men in the United States, with a particular emphasis on adolescent fathers. While considerable information on these outcomes for adolescent mothers is available (Miller and Moore, 1990; Waite and Moore, 1978; Teti and Lamb, 1989; Hofferth and Hayes, 1987; Chilman, 1980), there is a relative dearth of information on adolescent fathers. Roughly, 7 percent of young men become fathers in their teens, and the majority of these young fathers live apart from their children (Pirog-Good, 1992; Marsiglio, 1987). The questions of their human capital investments and short- and long-term employment experiences are particularly important in light of the increasing trends of nonmarital births to adolescents and the impoverishment of nearly one quarter of the children in the United States.

Furthermore, there are different patterns of findings concerning adolescent parenting, educational achievement, and labor market participation when race is taken into consideration. The structural shifts in the U.S. economy and the relocation of unskilled and semi-skilled jobs to relatively low wage countries have increased the educational and skills requirements for employment in the United States (Reich, 1983; Hamilton, 1990). This trend has had its most adverse impacts on innercity black populations (Wilson, 1987). Thus, the following discussion of the educational and labor market outcomes of young fathers will explicitly take race into consideration whenever possible.

Finally, prior research has shown that adolescent paternity is associated with a wide variety of socioeconomic variables (Pirog-Good, 1992; Marsiglio, 1987; Lerman, 1986). Overall, teen dads fare worse than their peers who delay parenting until their twenties or later along most of the socioeconomic dimensions considered. Teen fathers are more likely to come from minority, impoverished, single-parent households which have more siblings but less stability among the composition of household members (Pirog-Good, 1992). They are more likely to become involved 
with drugs and crime and at earlier ages (Lerman, 1986; Elster et. al., 1987; Pirog-Good, 1987, 1992; Good and Pirog-Good, 1989). It becomes unclear, then, whether their poorer performance in school and in the labor market is related to early paternity or rather related to the plethora of socioeconomic woes that are correlated with early fatherhood. That is, do educational and labor market deficits persist for young fathers even after controlling for the socioeconomic characteristics of these youths and their families? This question is also addressed in this article.

\section{$\underline{\text { Data and Methods }}$}

This study is based on data from the National Longitudinal Survey of Labor Market Experience-Youth Cohort (NLSY). The NLSY constitutes a balanced panel in which 6,403 young men who were fourteen to twenty-one in 1979 were interviewed annually up through 1988, the last year of data available for this study. Approximately 93 percent of the survey participants were interviewed each year. Further, because the NLSY oversampled blacks, Hispanics, and poor whites, the data contain a larger absolute number of teenage fathers than would be found in a nationally representative survey. There are over six hundred observations on young men who became fathers prior to the age of twenty in the data. Because of the attrition of some survey members and the oversampling of some groups, weights are provided in each survey year reflecting the probability of each person's inclusion in the sample such that national estimates may be generated from the data.

The NLSY surveys were conducted with well-trained interviewers and attention was focused on youth labor market experience rather than teen parenting. Nevertheless, the extent to which these data accurately reflect births to young men is unclear. Mott (1983) found that 28 percent of the NLSY male fertility records had a discrepancy that could not be resolved. The most common discrepancy was the late reporting of births, for example, the failure to report a birth that occurred prior to the 1980 survey until the 1981 survey. The late reports of births may have occurred because fathers were initially unaware of the birth or were unwilling to acknowledge their paternity. Given that the 
youngest respondents turned twenty in 1985 and that data up through 1988 are used in this study, there is a minimum of four years to capture the late reports of births. Hence, underreports of teen births are minimized in this study by using the full fertility history of male respondents. Moreover, Marsiglio (1987) correctly points out that the longitudinal nature of the NLSY permitted 41 percent of the discrepancies in the fertility records to be corrected. Cross-sectional data would not have afforded the opportunity to discover, much less correct, discrepancies such as those found in the NLSY.

There is, however, a related concern about the quality of the male fertility data, specifically the underreporting (not just late reporting) of births. A later study by Mott (1985) found that births to males may have been underreported in the NLSY by as much as 15 percent, with underreporting more pronounced among blacks. Again, the use of data through 1988 should help minimize underreporting, because some nonreports of births will eventually be recorded as late reports of births. Nevertheless, the likely underreporting of births has several implications for this study. First, because some teen fathers will be incorrectly classified as men who delayed parenting until age twenty or later, differences between teen fathers and other young men will be underestimated. Second, because underreporting was more pronounced among blacks, this problem will be more serious in estimates comparing black teen fathers and black males who delayed parenting. Third, Marsiglio (1987) has conjectured that the data may be biased towards males whose involvement in fatherhood is above average, given that they were willing to admit their paternity at least once over the survey period. Despite the obvious need to utilize these data cautiously, the wealth of information available (over 20,000 variables over an eleven-year period) makes it arguably the best available on teen fathers (Sonenstein, 1986; Card, 1986).

The bivariate results in the first five tables examine the educational and labor market outcomes of teen fathers and other young men as well as a variety of variables which are presumed to affect both education and labor market participation. The means presented in these tables make use of the 
weights available in the NLSY to generate national, rather than sample-specific, estimates. However, the actual number of observations on which the means are based are given in parentheses. Further, the statistical tests of significance, t-tests, reflect differences in the national percentages across categories but were calculated using the actual number of observations in the data set. Once weighted, the 6,403 NLSY observations reflect millions of young men in the United States who were fourteen to twentyone years old in 1979; using several million obviously non-independent observations in the statistical comparisons would render the comparisons inaccurate and always significant. Regression results were obtained using OLS and probit estimators, depending on whether the dependent variable was continuous or dichotomous.

\section{BIVARIATE EDUCATION RESULTS}

\section{$\underline{\text { Family Background }}$}

The effects of family background on the educational attainment of youth are often couched in terms of the "underclass" and the reproduction of poverty. In prior studies, family characteristics such as the educational attainment of parents, living in poverty, and living in a single-parent household have been found to be important in predicting school completion (Fernandez and Shu, 1988; Fine and Rosenberg, 1983; Ekstrom et al., 1986; Olsen and Farkas, 1988; Finn, 1987; Hetherington et al., 1983; Lerman, 1972). In addition to the above variables, the National Commission on Children (1991) has identified lack of fluency in English as a factor which places children at educational risk. Thus, to examine the effect of family background on the educational and labor market outcomes of young fathers, I examined the educational attainment of the mother, father, and eldest sibling; whether or not the youth lived in an impoverished household; whether or not the youth lived in a household with two parents at age fourteen; and whether or not a foreign language was spoken at home during the respondent's childhood. 
As shown in Table 1, the mothers of teen fathers completed fewer years of schooling than the mothers of young men who did not become teen fathers. This was true for all races. However, the difference was most pronounced among other races (males classified as nonwhites and nonblacks). The mothers of teen fathers of other races had 6.7 years of education, as opposed to 8.9 for women whose sons were not teen fathers, a difference of 2.2 years. Irrespective of the parenting status of their sons, women of other races also had the lowest levels of education. The educational difference was also pronounced among whites among whom the mothers of teen dads and nondads attained 10.7 and 11.9 years of education, respectively. While significant, the difference in the educational attainment of the mothers of teen fathers and of nonfathers was smallest among blacks, 10.7 versus 11.1 years, respectively.

The fathers of teen dads also attained significantly less education than the fathers of young men who waited until age twenty or later to become parents. Taken as a group, the fathers of males who became parents prior to age twenty attained 10.4 years of education, 1.6 fewer than the fathers of other young men. When race was considered, however, this finding held for whites and other races only. Among these two groups, the educational differences were greatest among other races. Achieving the lowest levels of education, the fathers of teen dads of other races attained, on average, 7.5 years of schooling, 2.1 years fewer than the fathers of young men of other races who deferred parenting. Among whites, the educational levels of the fathers of teen dads and other white males were 10.6 and 12.3 years, respectively.

The educational attainment of the eldest siblings was also examined. Overall, the eldest siblings of teen dads were older than those of other young men, but had acquired roughly 10 fewer 
TABLE 1

Family Background of Males Aged 14-21 in 1979

\begin{tabular}{|c|c|c|c|c|c|c|c|c|}
\hline & \multicolumn{2}{|c|}{ All } & \multicolumn{2}{|c|}{ Whites } & \multicolumn{2}{|c|}{ Blacks } & \multicolumn{2}{|c|}{ Others } \\
\hline & $\begin{array}{l}\text { Teen } \\
\text { Fathers }\end{array}$ & $\begin{array}{l}\text { Not Teen } \\
\text { Fathers }\end{array}$ & $\begin{array}{l}\text { Teen } \\
\text { Fathers }\end{array}$ & $\begin{array}{l}\text { Not Teen } \\
\text { Fathers }\end{array}$ & $\begin{array}{l}\text { Teen } \\
\text { Fathers }\end{array}$ & $\begin{array}{l}\text { Not Teen } \\
\text { Fathers }\end{array}$ & $\begin{array}{l}\text { Teen } \\
\text { Fathers }\end{array}$ & $\begin{array}{l}\text { Not Teen } \\
\text { Fathers }\end{array}$ \\
\hline $\begin{array}{l}\text { Mother's education, } \\
1979 \text { (yrs.) }\end{array}$ & $\begin{array}{l}10.548 * * * * \\
(595)\end{array}$ & $\begin{array}{l}11.746 * * * * \\
(5339)\end{array}$ & $\begin{array}{l}10.723 * * * * \\
(318)\end{array}$ & $\begin{array}{l}11.924 * * * * \\
(3821)\end{array}$ & $\begin{array}{l}10.736^{*} \\
(228)\end{array}$ & $\begin{array}{l}11.094^{*} \\
(1206)\end{array}$ & $\begin{array}{l}6.747 * * * \\
(45)\end{array}$ & $\begin{array}{l}8.936 * * * \\
(285)\end{array}$ \\
\hline $\begin{array}{l}\text { Father's education, } \\
1979 \text { (yrs.) }\end{array}$ & $\begin{array}{l}10.408^{* * * * *} \\
(530)\end{array}$ & $\begin{array}{l}12.014 * * * * \\
(4964)\end{array}$ & $\begin{array}{l}10.628 * * * * \\
(303)\end{array}$ & $\begin{array}{l}12.270 * * * * \\
(3675)\end{array}$ & $\begin{array}{l}10.316 \\
(181)\end{array}$ & $\begin{array}{l}10.471 \\
(1003)\end{array}$ & $\begin{array}{l}7.525 * * * \\
(42)\end{array}$ & $\begin{array}{l}9.684 * * * \\
(261)\end{array}$ \\
\hline $\begin{array}{l}\text { Number of siblings, } \\
1979\end{array}$ & $\begin{array}{l}4.150^{* * * * *} \\
(671)\end{array}$ & $\begin{array}{l}3.234 * * * * \\
(5723)\end{array}$ & $\begin{array}{l}3.719 * * * * \\
(356)\end{array}$ & $\begin{array}{l}3.011 * * * * \\
(4033)\end{array}$ & $\begin{array}{l}4.893 * * \\
(261)\end{array}$ & $\begin{array}{l}4.475^{* *} \\
(1344)\end{array}$ & $\begin{array}{l}5.340^{*} \\
(50)\end{array}$ & $\begin{array}{l}4.470^{*} \\
(315)\end{array}$ \\
\hline $\begin{array}{l}\text { Age of Oldest Sibling, } \\
1979\end{array}$ & $\begin{array}{l}25.081 * * * \\
(492)\end{array}$ & $\begin{array}{l}24.332 * * * \\
(4199)\end{array}$ & $\begin{array}{l}25.196 * * \\
(252)\end{array}$ & $\begin{array}{l}24.194 * * \\
(2878)\end{array}$ & $\begin{array}{l}24.990 \\
(202)\end{array}$ & $\begin{array}{l}25.015 \\
(1056)\end{array}$ & $\begin{array}{l}24.130 \\
(34)\end{array}$ & $\begin{array}{l}24.934 \\
(244)\end{array}$ \\
\hline $\begin{array}{l}\text { Highest grade } \\
\text { completed by eldest } \\
\text { sibling, } 1979\end{array}$ & $\begin{array}{l}11.648 * * * * \\
(483)\end{array}$ & $\begin{array}{l}12.467 * * * * \\
(4149)\end{array}$ & $\begin{array}{l}11.650 * * * * \\
(249)\end{array}$ & $\begin{array}{l}12.560 * * * * \\
(2849)\end{array}$ & $\begin{array}{l}11.770 * * \\
(199)\end{array}$ & $\begin{array}{l}12.008 * * \\
(1040)\end{array}$ & $\begin{array}{l}10.590^{*} \\
(31)\end{array}$ & $\begin{array}{l}11.632 * \\
(240)\end{array}$ \\
\hline $\begin{array}{l}\text { Household below } \\
\text { poverty threshold, } \\
1979(\%)\end{array}$ & $\begin{array}{l}25.2 * * * * \\
(587)\end{array}$ & $\begin{array}{l}12.2 * * * * \\
(5155)\end{array}$ & $\begin{array}{l}18.6 * * * * \\
(315)\end{array}$ & $\begin{array}{l}8.6 * * * * \\
(3665)\end{array}$ & $\begin{array}{l}38.4 \\
(229)\end{array}$ & $\begin{array}{l}34.7 \\
(1203)\end{array}$ & $\begin{array}{l}33.1 \\
(39)\end{array}$ & $\begin{array}{l}22.4 \\
(265)\end{array}$ \\
\hline $\begin{array}{l}\text { Lived without two } \\
\text { parents in household } \\
\text { at age } 14,1979\end{array}$ & $\begin{array}{l}26.7 * * * * \\
(660)\end{array}$ & $\begin{array}{l}16.3 * * * * \\
(5621)\end{array}$ & $\begin{array}{l}19.4 * * * * \\
(352)\end{array}$ & $\begin{array}{l}12.4 * * * * \\
(3956)\end{array}$ & $\begin{array}{l}42.8 \\
(254)\end{array}$ & $\begin{array}{l}40.0 \\
(1324)\end{array}$ & $\begin{array}{l}25.1 \\
(50)\end{array}$ & $\begin{array}{l}25.0 \\
(310)\end{array}$ \\
\hline $\begin{array}{l}\text { Foreign language } \\
\text { spoken at home } \\
\text { during childhood, } 1979\end{array}$ & $\begin{array}{l}16.1 \\
9^{(670)}\end{array}$ & $\begin{array}{l}14.4 \\
(5732)\end{array}$ & $\begin{array}{l}17.7 * \\
(355)\end{array}$ & $\begin{array}{l}13.8^{*} \\
(4037)\end{array}$ & $\begin{array}{l}3.7 \\
(261)\end{array}$ & $\begin{array}{l}3.6 \\
(1349)\end{array}$ & $\begin{array}{l}77.6 \\
(50)\end{array}$ & $\begin{array}{l}84.7 \\
(315)\end{array}$ \\
\hline $\begin{array}{l}\text { Any } \mathrm{HH} \text { member } \\
\text { received magazines } \\
\text { when respondent was } \\
14(\%)\end{array}$ & $\begin{array}{l}48.1 * * * * \\
(668)\end{array}$ & $\begin{array}{l}67.9 * * * * \\
(5684)\end{array}$ & $\begin{array}{l}53.9 * * * * \\
(356)\end{array}$ & $\begin{array}{l}72.4 * * * * \\
(4004)\end{array}$ & $\begin{array}{l}38.2 \\
(259)\end{array}$ & $\begin{array}{l}43.4 \\
(1339)\end{array}$ & $\begin{array}{l}27.5^{* *} \\
(49)\end{array}$ & $\begin{array}{l}44.7 * * \\
(313)\end{array}$ \\
\hline $\begin{array}{l}\text { Any } \mathrm{HH} \text { member } \\
\text { received newspaper } \\
\text { when respondent was } \\
14(\%)\end{array}$ & $\begin{array}{l}74.8 * * * * \\
(670)\end{array}$ & $\begin{array}{l}84.9 * * * * \\
(5712)\end{array}$ & $\begin{array}{l}79.9 * * * * \\
(356)\end{array}$ & $\begin{array}{l}88.1 * * * * \\
(4026)\end{array}$ & $\begin{array}{l}67.5 \\
(260)\end{array}$ & $\begin{array}{l}69.0 \\
(1341)\end{array}$ & $\begin{array}{l}54.7 \\
(50)\end{array}$ & $\begin{array}{l}60.2 \\
(314)\end{array}$ \\
\hline $\begin{array}{l}\text { Any } \mathrm{HH} \text { member had a } \\
\text { library card when } \\
\text { respondent was } 14(\%)\end{array}$ & $\begin{array}{l}60.5 * * * * \\
(670) \\
\end{array}$ & $\begin{array}{l}74.7 * * * * \\
(5709)\end{array}$ & $\begin{array}{l}58.9 * * * * \\
(356)\end{array}$ & $\begin{array}{l}76.6 * * * * \\
(4024)\end{array}$ & $\begin{array}{l}65.6 \\
(261)\end{array}$ & $\begin{array}{l}64.5 \\
(1341)\end{array}$ & $\begin{array}{l}46.3^{* *} \\
(49)\end{array}$ & $\begin{array}{l}63.2 * * \\
(313)\end{array}$ \\
\hline
\end{tabular}

Source: Author's computations based on the National Longitudinal Survey of Labor Market Experience-Youth Cohort.

Significance levels: $* * * *=p<.001, * * *=p<.01, * *=p<.05, *=p<.10$ 
months of education. This result held for whites, with an educational difference of 11 months. For blacks and other races, the age of the eldest siblings did not differ significantly, but the eldest siblings of teen dads had acquired less education than the eldest siblings of young men who deferred parenting. The educational deficits of the eldest siblings were 3 months and 12.5 months for blacks and other races, respectively.

Turning to the economic background of young men, males who ultimately became teen fathers were more than twice as likely to have lived in households below the poverty level in 1979 , the first survey year. The increased likelihood of living in poverty was most pronounced for whites, and while the differences for black and other races were statistically insignificant. In 1979, white teen fathers were more than twice as likely to live in a poor household than their peers. Approximately 18.6 percent of white teen dads lived in poverty households in 1979, in contrast to 8.6 percent of white males who never became teen dads. Blacks and young men of other races were more likely to live in poverty relative to whites, irrespective of their status as parents.

Regarding household composition, a variable was constructed which indicated whether or not the respondent lived with two biological, step, or adoptive parents at age fourteen. Overall, males who never became teen fathers were more likely to have lived with two parents at age fourteen. Approximately 26.7 percent of teen fathers were not living with two parents at age fourteen, in comparison to 16.3 percent of young men who delayed parenting until age twenty or later. This result held only for whites, however, when race-specific estimates were calculated. Black adolescents were by far the least likely to live with both parents at age fourteen; approximately 40 percent of black males were not living in a two-parent household during early adolescence.

While speaking a foreign language in the home was examined, significant differences were not found to exist between teen fathers and other young men, except among whites. Among whites, 17.7 
percent of teen fathers in contrast to 13.8 percent of non-teen-fathers came from households where a foreign language was spoken during childhood.

Finally, with respect to the home lives of young males, respondents were asked if, when they were fourteen, they or anyone else living in their household regularly received magazines, a newspaper, or had a library card. These results, also shown in Table 1, indicate that the households of teen fathers were substantially less likely to receive magazines (48.1 percent versus 67.9 percent) or newspapers (74.8 percent versus 84.9 percent). Additionally, teen fathers lived in households which were 14.2 percent less likely to have a household member with a library card (only 60.5 percent of these households had a member with a library card). When these differences were examined by race, the households of white teen fathers were substantially less likely to receive magazines, newspapers, or have a member with a library card. Teen fathers of other races were less likely to live in homes with magazines or with members possessing a library card. No such differences were found concerning the households of black teen fathers and their black adolescent peers.

\section{Attitudes Towards School, Educational Expectations, Aspirations, and Outcomes}

Bivariate results concerning the attitudes of teen fathers towards school as well as their educational expectations, aspirations, and outcomes are shown in Table 2. In 1979, respondents were asked if they were satisfied with school. Most respondents, 84.8 percent of the teen fathers and 88.5 percent of the nonfathers, indicated that they were either somewhat satisfied or very satisfied with school (result not shown in Table 2). Nevertheless, the average school satisfaction rating was significantly lower among teen fathers. When race was taken into consideration, however, such differences existed only among whites. That is, white teen fathers had significantly lower school satisfaction ratings than other white males. Although not shown in Table 2, teen fathers were divided into two groups, young men who had already become teen fathers and those who would eventually 
TABLE 2

Attitudes Towards School, Educational

Expectations, Aspirations, and Outcomes: Males Aged 14-21 in 1979

\begin{tabular}{|c|c|c|c|c|c|c|c|c|}
\hline & \multicolumn{2}{|c|}{ All } & \multicolumn{2}{|c|}{ Whites } & \multicolumn{2}{|c|}{ Blacks } & \multicolumn{2}{|c|}{ Others } \\
\hline & $\begin{array}{l}\text { Teen } \\
\text { Fathers }\end{array}$ & $\begin{array}{l}\text { Not Teen } \\
\text { Fathers }\end{array}$ & $\begin{array}{l}\text { Teen } \\
\text { Fathers }\end{array}$ & $\begin{array}{l}\text { Not Teen } \\
\text { Fathers }\end{array}$ & $\begin{array}{l}\text { Teen } \\
\text { Fathers }\end{array}$ & $\begin{array}{l}\text { Not Teen } \\
\text { Fathers }\end{array}$ & $\begin{array}{l}\text { Teen } \\
\text { Fathers }\end{array}$ & $\begin{array}{l}\text { Not Teen } \\
\text { Fathers }\end{array}$ \\
\hline $\begin{array}{l}\text { R's attitude towards } \\
\text { school, } 1979 \text { (1=very } \\
\text { dissatisfied, 4=very } \\
\text { satisfied) }\end{array}$ & $\begin{array}{l}3.100^{* *} \\
(285)\end{array}$ & $\begin{array}{l}3.300^{* *} \\
(2638)\end{array}$ & $\begin{array}{l}3.072 * * * \\
(128)\end{array}$ & $\begin{array}{l}3.274 * * \\
(1786)\end{array}$ & $\begin{array}{l}3.222 \\
(129)\end{array}$ & $\begin{array}{l}3.209 \\
(709)\end{array}$ & $\begin{array}{l}3.389 \\
(26)\end{array}$ & $\begin{array}{l}3.289 \\
(132)\end{array}$ \\
\hline $\begin{array}{l}\text { Education level R } \\
\text { would like to achieve, } \\
1979\end{array}$ & $\begin{array}{l}13.600 * * * * \\
(663)\end{array}$ & $\begin{array}{l}14.500 * * * * \\
(5627)\end{array}$ & $\begin{array}{l}13.220 * * * * \\
(225)\end{array}$ & $\begin{array}{l}14.440 \text { **** } \\
(4091)\end{array}$ & $\begin{array}{l}14.240 * * * * \\
(165)\end{array}$ & $\begin{array}{l}14.400 * * * * \\
(1416)\end{array}$ & $\begin{array}{l}12.760 * * * * \\
(25)\end{array}$ & $\begin{array}{l}14.190 * * * * \\
(335)\end{array}$ \\
\hline $\begin{array}{l}\text { Education level R } \\
\text { expects to achieve, } \\
1979\end{array}$ & $\begin{array}{l}12.700 * * * * \\
(663)\end{array}$ & $\begin{array}{l}13.900 * * * * \\
(5627)\end{array}$ & $\begin{array}{l}12.130 * * * * \\
(225)\end{array}$ & $\begin{array}{l}13.860 \text { **** } \\
(4091)\end{array}$ & $\begin{array}{l}13.350 * * * * \\
(165)\end{array}$ & $\begin{array}{l}13.820 * * * * \\
(1416)\end{array}$ & $\begin{array}{l}12.160 * * * * \\
(25)\end{array}$ & $\begin{array}{l}13.470 * * * * \\
(335)\end{array}$ \\
\hline $\begin{array}{l}\text { Education level } \mathrm{R} \\
\text { would like to achieve, } \\
1981\end{array}$ & $\begin{array}{l}13.500 * * * * \\
(644)\end{array}$ & $\begin{array}{l}14.400 * * * * \\
(5444)\end{array}$ & $\begin{array}{l}13.190 * * * * \\
(298)\end{array}$ & $\begin{array}{l}14.410^{* * * * *} \\
(3875)\end{array}$ & $\begin{array}{l}14.100 * * * * \\
(221)\end{array}$ & $\begin{array}{l}14.510^{* * * * *} \\
(1327)\end{array}$ & $\begin{array}{l}13.650 * * * * \\
(38)\end{array}$ & $\begin{array}{l}14.320 * * * * \\
(297)\end{array}$ \\
\hline $\begin{array}{l}\text { Education level R } \\
\text { expects to achieve, } \\
1981\end{array}$ & $\begin{array}{l}12.600 * * * * \\
(644)\end{array}$ & $\begin{array}{l}13.900 * * * * \\
(5444)\end{array}$ & $\begin{array}{l}12.150 * * * * \\
(298)\end{array}$ & $\begin{array}{l}13.850 \text { **** } \\
(3875)\end{array}$ & $\begin{array}{l}13.330 * * * * \\
(221)\end{array}$ & $\begin{array}{l}13.920^{* * * *} \\
(1327)\end{array}$ & $\begin{array}{l}11.870 * * * * \\
(38)\end{array}$ & $\begin{array}{l}13.820 * * * * \\
(297)\end{array}$ \\
\hline $\begin{array}{l}\text { Education level R } \\
\text { would like to achieve, } \\
1982\end{array}$ & $\begin{array}{l}13.600 * * * * \\
(640)\end{array}$ & $\begin{array}{l}14.500 * * * * \\
(5437)\end{array}$ & $\begin{array}{l}13.120^{* * * * *} \\
(322)\end{array}$ & $\begin{array}{l}14.450 \text { **** } \\
(3855)\end{array}$ & $\begin{array}{l}14.160 * * * * \\
(239)\end{array}$ & $\begin{array}{l}14.630^{* * * * *} \\
(1292)\end{array}$ & $\begin{array}{l}13.790 * * * * \\
(47)\end{array}$ & $\begin{array}{l}14.470 * * * * \\
(291)\end{array}$ \\
\hline $\begin{array}{l}\text { Education level R } \\
\text { expects to achieve, } \\
1982\end{array}$ & $\begin{array}{l}12.700 * * * * \\
(640)\end{array}$ & $\begin{array}{l}14.000 * * * * \\
(5437)\end{array}$ & $\begin{array}{l}12.220 * * * * \\
(322)\end{array}$ & $\begin{array}{l}13.930 * * * * \\
(3855)\end{array}$ & $\begin{array}{l}13.370 * * * * \\
(239)\end{array}$ & $\begin{array}{l}14.100 * * * * \\
(1292)\end{array}$ & $\begin{array}{l}12.530 * * * * \\
(47)\end{array}$ & $\begin{array}{l}13.800 * * * * \\
(291)\end{array}$ \\
\hline $\begin{array}{l}\text { Average years of } \\
\text { education completed } \\
\text { by } 1988\end{array}$ & $\begin{array}{l}10.972 * * * * \\
(551)\end{array}$ & $\begin{array}{l}13.137 * * * * \\
(4576)\end{array}$ & $\begin{array}{l}10.775^{* * * *} \\
(277)\end{array}$ & $\begin{array}{l}13.284 * * * * \\
(3185)\end{array}$ & $\begin{array}{l}11.457 * * * * \\
(229)\end{array}$ & $\begin{array}{l}12.374 * * * * \\
(1134)\end{array}$ & $\begin{array}{l}10.173 * * * * \\
(42)\end{array}$ & $\begin{array}{l}12.235^{* * * * *} \\
(234)\end{array}$ \\
\hline $\begin{array}{l}\text { Proportion received } \\
\text { H.S. diploma or GED } \\
\text { by } 1988\end{array}$ & $\begin{array}{l}63.560 * * * * \\
(551)\end{array}$ & $\begin{array}{l}87.632 * * * * \\
(4550)\end{array}$ & $\begin{array}{l}59.318 * * * * \\
(280)\end{array}$ & $\begin{array}{l}89.090 \text { **** } \\
(3171)\end{array}$ & $\begin{array}{l}74.305^{* *} \\
(227)\end{array}$ & $\begin{array}{l}80.766^{* *} \\
(1122)\end{array}$ & $\begin{array}{l}48.789 * * * * \\
(41)\end{array}$ & $\begin{array}{l}76.618 * * * * \\
(234)\end{array}$ \\
\hline $\begin{array}{l}\text { Average age received } \\
\text { H.S. diploma or GED }\end{array}$ & $\begin{array}{l}19.100 * * * * \\
(401)\end{array}$ & $\begin{array}{l}18.500 * * * * \\
(4535)\end{array}$ & $\begin{array}{l}19.081^{* * * * *} \\
(195)\end{array}$ & $\begin{array}{l}18.425 * * * * \\
(3272)\end{array}$ & $\begin{array}{l}18.905^{*} \\
(178)\end{array}$ & $\begin{array}{l}18.692 * \\
(1017)\end{array}$ & $\begin{array}{l}18.866 \\
(26)\end{array}$ & $\begin{array}{l}18.679 \\
(220)\end{array}$ \\
\hline
\end{tabular}

Source: Author's computations based on the National Longitudinal Survey of Labor Market Experience-Youth Cohort.

Note: Results for education levels in rows 2 through 6 are expressed in number of years.

Significance levels: $* * * *=\mathrm{p}<.001, * * *=\mathrm{p}<.01, * *=\mathrm{p}<.05, *=\mathrm{p}<.10$. 
become teen fathers. In this comparison, school satisfaction ratings were lowest among young men who had become teen dads, followed by young men who eventually became teen dads, with the highest ratings given by young men who were never teen parents. This implies that teen fathers may be disillusioned with school prior to the birth of their first child but become even more dissatisfied after they have their first child.

In 1979, 1981, and 1982, survey respondents were asked how many years of education they expected and wanted to complete. Among all races and irrespective of parenting status, the young men generally wished to complete more years of education than they actually thought they would complete. Teen fathers expected to complete fewer years of education than young men who deferred parenting; the differences were significant in all three survey years and for all races. The difference was most pronounced among whites: according to the 1982 survey, white teen fathers expected to complete 1.7 fewer years of education than white males who delayed parenting until age twenty or later. Similarly, the educational aspirations of teen fathers were lower than those of their peers. This result held for all races and across the three survey years, again with the largest differences occurring among whites. In 1982, white teen fathers wanted to complete 13.1 years of school, which was, on average, 1.3 years fewer than other white males. The educational expectations and aspirations of young men who would eventually become teen fathers were also compared with those of young men who had already become teen dads (result not shown in Table 2). Males who had not yet become (but who would become) teen fathers had the lowest educational expectations and aspirations. However, the educational expectations and aspirations of young men who were already teen dads were still lower than those of young men who were never teen dads. Thus, while young men who had already become teen fathers had the lowest school satisfaction ratings, they desired and expected to achieve higher levels of education than young men who had not yet but would eventually become teen fathers. This might have occurred simply because the young men who had already become teen fathers were 
generally older than the young men who eventually became teen fathers. Alternatively, this may suggest that births to teenage males increase their resolve to complete more years of education despite their lower satisfaction with school.

Regarding educational outcomes, teen fathers had acquired less education by 1988 than young men who deferred parenting until age twenty or later. This result was significant for all races, but the difference was most pronounced among whites. White males who became parents in their teens attained an average of 10.8 as opposed to 13.3 years of education, a difference of 2.5 years. There was a substantial difference of 2 years in the educational attainment of males of other races by parenting status. Teen dads of other races attained 10.2 years of education in comparison to 12.2 years. While significant, the difference in the educational attainment among blacks was the smallest at 0.9 years. In fact, black teen fathers achieved more education than teen fathers of any other race, 11.5 years.

The lower educational attainment of teen fathers was also reflected in the smaller percentages of teen dads who had received their high school diploma or GED by 1988. Again, the differences were most pronounced among males of white and other races. Among whites, 59.3 percent of teen dads and 89.0 percent of other males had finished high school or earned their GED by 1988, a difference of 29.7 percent. Far fewer teen dads of other races, 48.8 percent, had received high school credentials by 1988. An additional 27.8 percent of males of other races who deferred parenting had finished high school or a GED. Among blacks, 6.5 percent fewer teen dads had received their high school certification by 1988. Consistent with their higher overall level of education, black teen fathers, in comparison to teen fathers of any other race, were the most likely to have received high school certification, with 74.3 percent receiving a diploma or GED by $1988 .{ }^{1}$

The age at which the high school diploma or GED was achieved was also examined. White and black teen fathers attained high school diplomas at later ages than their nonfather peers. This 
difference was largest among whites, among whom teen dads obtained their high school credentials approximately 7.9 months later than their nonfather peers. While significant, this difference was only 2.6 months for blacks. There were no significant differences among men of other races along this dimension.

\section{BIVARIATE LABOR MARKET RESULTS}

\section{$\underline{\text { Work Commitment }}$}

In 1979, respondents were asked what they would probably do if they were unable to support their family. The options included seeking more education, going on welfare, entering training, applying for food stamps, and shoplifting. No differences were found in the willingness to go on welfare or seek more education. However, as shown in Table 3, teen fathers were significantly more likely to indicate a willingness to enter training, apply for food stamps, and shoplift. The largest difference occurred in the willingness to apply for food stamps, with 6.3 percent more teen dads indicating that they would apply for food stamps. However, when asked if they would work even if they could live comfortably without working, 83.6 percent of teen fathers indicated that they would prefer to work. This figure was not significantly different from the 84.5 percent of males who were not teen dads who indicated a preference for work, even if they could live comfortably without working.

Average Hourly Wage. As shown in Table 4, average hourly wages of respondents in 1988 dollars were calculated for teen fathers and other males between the ages of eighteen and twenty-nine. At and below age twenty-one, teen fathers earned more on an hourly basis than their peers. These differences in hourly wages were significant in three of the four years measured. Between the ages of twenty-two and twenty-six, the wages of teen fathers and other young men were not significantly different from each other. However, from age twenty-seven on, the hourly wages of teen fathers 
TABLE 3

Work Commitment of Males Aged 14-21 in 1979

\begin{tabular}{|c|c|c|c|c|c|c|c|c|}
\hline & \multicolumn{2}{|c|}{ All } & \multicolumn{2}{|c|}{ Whites } & \multicolumn{2}{|c|}{ Blacks } & \multicolumn{2}{|c|}{ Others } \\
\hline & $\begin{array}{l}\text { Teen } \\
\text { Fathers }\end{array}$ & $\begin{array}{l}\text { Not Teen } \\
\text { Fathers }\end{array}$ & $\begin{array}{l}\text { Teen } \\
\text { Fathers }\end{array}$ & $\begin{array}{l}\text { Not Teen } \\
\text { Fathers }\end{array}$ & $\begin{array}{l}\text { Teen } \\
\text { Fathers }\end{array}$ & $\begin{array}{l}\text { Not Teen } \\
\text { Fathers }\end{array}$ & $\begin{array}{l}\text { Teen } \\
\text { Fathers }\end{array}$ & $\begin{array}{l}\text { Not Teen } \\
\text { Fathers }\end{array}$ \\
\hline \multicolumn{9}{|c|}{$\begin{array}{l}\text { If unable to support one's family the R probably } \\
\text { would (1)/probably would not }(0) \text { : }\end{array}$} \\
\hline $\begin{array}{l}\text { Seek more education } \\
(\%)\end{array}$ & $\begin{array}{l}.882 \\
(666)\end{array}$ & $\begin{array}{l}.862 \\
(5676)\end{array}$ & $\begin{array}{l}.849 \\
(355)\end{array}$ & $\begin{array}{l}.851 \\
(3996)\end{array}$ & $\begin{array}{l}.950 \\
(259)\end{array}$ & $\begin{array}{l}.923 \\
(1338)\end{array}$ & $\begin{array}{l}.898 \\
(48)\end{array}$ & $\begin{array}{l}.925 \\
(312)\end{array}$ \\
\hline Go on welfare (\%) & $\begin{array}{l}.254 \\
(656)\end{array}$ & $\begin{array}{l}.258 \\
(5622)\end{array}$ & $\begin{array}{l}.215 \\
(347)\end{array}$ & $\begin{array}{l}.250 \\
(3960)\end{array}$ & $\begin{array}{l}.325 \\
(255)\end{array}$ & $\begin{array}{l}.314 \\
(1325)\end{array}$ & $\begin{array}{l}.354 \\
(50)\end{array}$ & $\begin{array}{l}.290 \\
(306)\end{array}$ \\
\hline Enter training $(\%)$ & $\begin{array}{l}.968^{*} \\
(668)\end{array}$ & $\begin{array}{l}.949^{*} \\
(5685)\end{array}$ & $\begin{array}{l}.966 \\
(355)\end{array}$ & $\begin{array}{l}.947 \\
(4005)\end{array}$ & $\begin{array}{l}.971 \\
(259)\end{array}$ & $\begin{array}{l}.957 \\
(1338)\end{array}$ & $\begin{array}{l}.980 \\
(50)\end{array}$ & $\begin{array}{l}.978 \\
(311)\end{array}$ \\
\hline $\begin{array}{l}\text { Apply for food } \\
\text { stamps }(\%)\end{array}$ & $\begin{array}{l}.477 * * * \\
(664)\end{array}$ & $\begin{array}{l}.414 * * * \\
(5624)\end{array}$ & $\begin{array}{l}.446 \\
(353)\end{array}$ & $\begin{array}{l}.401 \\
(3963)\end{array}$ & $\begin{array}{l}.477 \\
(258)\end{array}$ & $\begin{array}{l}.414 \\
(1324)\end{array}$ & $\begin{array}{l}.465 \\
(49)\end{array}$ & $\begin{array}{l}.403 \\
(307)\end{array}$ \\
\hline Shoplift (\%) & $\begin{array}{l}.047 * \\
(663)\end{array}$ & $\begin{array}{l}.031^{*} \\
(5682)\end{array}$ & $\begin{array}{l}.045 \\
(355)\end{array}$ & $\begin{array}{l}.031 \\
(4011)\end{array}$ & $\begin{array}{l}.040^{*} \\
(256)\end{array}$ & $\begin{array}{l}.022^{*} \\
(1335)\end{array}$ & $\begin{array}{l}.121 * * \\
(48)\end{array}$ & $\begin{array}{l}.046^{* *} \\
(306)\end{array}$ \\
\hline $\begin{array}{l}\text { Would } \mathrm{R} \text { work if he } \\
\text { could live } \\
\text { comfortably w/o } \\
\text { working }(1=\text { yes, } 0=\text { no }\end{array}$ & $\begin{array}{l}.836 \\
(669)\end{array}$ & $\begin{array}{l}.845 \\
(5719)\end{array}$ & $\begin{array}{l}.831 \\
(355)\end{array}$ & $\begin{array}{l}.846 \\
(4026)\end{array}$ & $\begin{array}{l}.845 \\
(260)\end{array}$ & $\begin{array}{l}.861 \\
(1347)\end{array}$ & $\begin{array}{l}.865 \\
(50)\end{array}$ & $\begin{array}{l}.774 \\
(315)\end{array}$ \\
\hline
\end{tabular}

Source: Author's computations based on the NLSY.

Significance levels: $* * * *=\mathrm{p}<.001, * * *=\mathrm{p}<.01, * *=\mathrm{p}<.05, *=\mathrm{p}<.10$. 
TABLE 4

Average Hourly Wages of Males at Various Ages (Adjusted to 1988 Dollars)

\begin{tabular}{|c|c|c|c|c|c|c|c|c|}
\hline \multirow[b]{2}{*}{ Age } & \multicolumn{2}{|c|}{ All } & \multicolumn{2}{|c|}{ Whites } & \multicolumn{2}{|c|}{ Blacks } & \multicolumn{2}{|c|}{ Others } \\
\hline & $\begin{array}{l}\text { Teen } \\
\text { Fathers }\end{array}$ & $\begin{array}{l}\text { Not Teen } \\
\text { Fathers }\end{array}$ & $\begin{array}{l}\text { Teen } \\
\text { Fathers }\end{array}$ & $\begin{array}{l}\text { Not Teen } \\
\text { Fathers }\end{array}$ & $\begin{array}{l}\text { Teen } \\
\text { Fathers }\end{array}$ & $\begin{array}{l}\text { Not Teen } \\
\text { Fathers }\end{array}$ & $\begin{array}{l}\text { Teen } \\
\text { Fathers }\end{array}$ & $\begin{array}{l}\text { Not Teen } \\
\text { Fathers }\end{array}$ \\
\hline 18 & $\begin{array}{l}3.94 * * \\
(239)\end{array}$ & $\begin{array}{l}2.93 * * \\
(1822)\end{array}$ & $\begin{array}{l}4.84 * * * \\
(135)\end{array}$ & $\begin{array}{l}2.90 * * * \\
(1313)\end{array}$ & $\begin{array}{l}2.68 \\
(90)\end{array}$ & $\begin{array}{l}3.10 \\
(415)\end{array}$ & $\begin{array}{l}3.43 * * \\
(14)\end{array}$ & $\begin{array}{l}2.67 * * \\
(87)\end{array}$ \\
\hline 19 & $\begin{array}{l}3.45 \\
(335)\end{array}$ & $\begin{array}{l}3.27 \\
(2704)\end{array}$ & $\begin{array}{l}3.61 \\
(186)\end{array}$ & $\begin{array}{l}3.36 \\
(1978)\end{array}$ & $\begin{array}{l}3.08 \\
(120)\end{array}$ & $\begin{array}{l}3.02 \\
(582)\end{array}$ & $\begin{array}{l}4.15^{* * * *} \\
(27)\end{array}$ & $\begin{array}{l}3.07 * * * \\
(131)\end{array}$ \\
\hline 20 & $\begin{array}{l}4.11 * * * \\
(413)\end{array}$ & $\begin{array}{l}3.81 * * * \\
(3271)\end{array}$ & $\begin{array}{l}4.34 * * * \\
(235)\end{array}$ & $\begin{array}{l}3.90 * * * \\
(2377)\end{array}$ & $\begin{array}{l}3.65 \\
(143)\end{array}$ & $\begin{array}{l}3.45 \\
(713)\end{array}$ & $\begin{array}{l}4.61 \\
(33)\end{array}$ & $\begin{array}{l}4.01 \\
(163)\end{array}$ \\
\hline 21 & $\begin{array}{l}4.61 * * * \\
(476)\end{array}$ & $\begin{array}{l}4.31 * * * \\
(3876)\end{array}$ & $\begin{array}{l}4.79 * * * \\
(261)\end{array}$ & $\begin{array}{l}4.40 * * * \\
(2825)\end{array}$ & $\begin{array}{l}4.36 * * \\
(178)\end{array}$ & $\begin{array}{l}4.00 * * \\
(833)\end{array}$ & $\begin{array}{l}4.71 \\
(34)\end{array}$ & $\begin{array}{l}4.26 \\
(200)\end{array}$ \\
\hline 22 & $\begin{array}{l}5.08 \\
(490)\end{array}$ & $\begin{array}{l}5.05 \\
(4157)\end{array}$ & $\begin{array}{l}5.29 \\
(269)\end{array}$ & $\begin{array}{l}5.20 \\
(3046)\end{array}$ & $\begin{array}{l}4.71 \\
(185)\end{array}$ & $\begin{array}{l}4.61 \\
(888)\end{array}$ & $\begin{array}{l}5.70 \\
(33)\end{array}$ & $\begin{array}{l}4.89 \\
(200)\end{array}$ \\
\hline 23 & $\begin{array}{l}5.78 \\
(509)\end{array}$ & $\begin{array}{l}6.11 \\
(4327)\end{array}$ & $\begin{array}{l}6.03 \\
(278)\end{array}$ & $\begin{array}{l}6.33 \\
(3170)\end{array}$ & $\begin{array}{l}5.32 \\
(192)\end{array}$ & $\begin{array}{l}5.39 \\
(927)\end{array}$ & $\begin{array}{l}6.33 \\
(36)\end{array}$ & $\begin{array}{l}5.85 \\
(207)\end{array}$ \\
\hline 24 & $\begin{array}{l}6.25 \\
(436)\end{array}$ & $\begin{array}{l}6.82 \\
(3884)\end{array}$ & $\begin{array}{l}6.51 \\
(242)\end{array}$ & $\begin{array}{l}6.96 \\
(2823)\end{array}$ & $\begin{array}{l}5.83 \\
(161)\end{array}$ & $\begin{array}{l}6.45 \\
(846)\end{array}$ & $\begin{array}{l}6.45 \\
(31)\end{array}$ & $\begin{array}{l}6.38 \\
(194)\end{array}$ \\
\hline 25 & $\begin{array}{l}7.55 \\
(366)\end{array}$ & $\begin{array}{l}7.31 \\
(3282)\end{array}$ & $\begin{array}{l}7.53 \\
(200)\end{array}$ & $\begin{array}{l}7.46 \\
(2380)\end{array}$ & $\begin{array}{l}7.64 \\
(145)\end{array}$ & $\begin{array}{l}6.43 \\
(714)\end{array}$ & $\begin{array}{l}7.26 \\
(19)\end{array}$ & $\begin{array}{l}8.82 \\
(169)\end{array}$ \\
\hline 26 & $\begin{array}{l}8.53 \\
(292)\end{array}$ & $\begin{array}{l}8.40 \\
(2621)\end{array}$ & $\begin{array}{l}8.84 \\
(154)\end{array}$ & $\begin{array}{l}8.36 \\
(1902)\end{array}$ & $\begin{array}{l}8.38 \\
(121)\end{array}$ & $\begin{array}{l}8.24 \\
(576)\end{array}$ & $\begin{array}{l}6.93 \\
(15)\end{array}$ & $\begin{array}{l}9.72 \\
(129)\end{array}$ \\
\hline 27 & $\begin{array}{l}7.54 * * \\
(220)\end{array}$ & $\begin{array}{l}9.03 * * \\
(1930)\end{array}$ & $\begin{array}{l}8.22 \\
(123)\end{array}$ & $\begin{array}{l}9.28 \\
(1397)\end{array}$ & $\begin{array}{l}6.64 * \\
(84)\end{array}$ & $\begin{array}{l}7.77 * \\
(423)\end{array}$ & $\begin{array}{l}6.91 \\
(11)\end{array}$ & $\begin{array}{l}11.22 \\
(98)\end{array}$ \\
\hline 28 & $\begin{array}{l}8.36^{* * *} \\
(144)\end{array}$ & $\begin{array}{l}9.59 * * \\
(1407)\end{array}$ & $\begin{array}{l}9.05 \\
(86)\end{array}$ & $\begin{array}{l}10.16 \\
(1015)\end{array}$ & $\begin{array}{l}7.55 \\
(49)\end{array}$ & $\begin{array}{l}7.63 \\
(308)\end{array}$ & $\begin{array}{l}6.28 \\
(7)\end{array}$ & $\begin{array}{l}9.80 \\
(77)\end{array}$ \\
\hline 29 & $\begin{array}{l}7.29 * * * \\
(76)\end{array}$ & $\begin{array}{l}10.91 * * * \\
(910)\end{array}$ & $\begin{array}{l}7.84 * * \\
(38)\end{array}$ & $\begin{array}{l}11.66^{* *} \\
(657)\end{array}$ & $\begin{array}{l}6.67 * * \\
(33)\end{array}$ & $\begin{array}{l}8.66^{* *} \\
(195)\end{array}$ & $\begin{array}{l}6.67 \\
(3)\end{array}$ & $\begin{array}{l}9.96 \\
(53)\end{array}$ \\
\hline
\end{tabular}

Source: Author's computations based on the NLSY.

Significance levels: $* * * *=p<.001, * * *=p<.01, * *=p<.05, *=p<.10$ 
were significantly lower than those of males who had children at age twenty or later. A similar pattern was found for all races, although there were some differences across races at ages at which the wage differentials were significant.

Average Income. The average annual income of respondents expressed in 1988 dollars is shown for respondents between the ages of eighteen and twenty-nine in Table 5. A pattern similar to that found in the hourly wage data appeared. Roughly, teen fathers earned more than their peers in their teen years, earned similar incomes in their early twenties, and fell behind in earnings in their midto late twenties. The pattern for whites was similar; however, there was a two year period over which the incomes of white teen fathers were similar to those of the rest of their cohort. The incomes of white teen fathers fell behind those of their cohort at age twenty-four. By age twenty-nine, white teen fathers earned $\$ 7,614$ less than the $\$ 22,937$ earned by young white men who had not been teen fathers. While the pattern was similar for blacks, the period of similarity of incomes between teen dads and black males who deferred parenting lasted six years, three times as long as the period of similarity for whites. However, by age twenty-nine, the income differential was $\$ 7,210$, with black males who were teen fathers earning slightly more than half of the $\$ 15,384$ earned by black men who were not teen fathers. While the age income profiles for teen fathers of other races and their peers followed the same general pattern, the number of observations for comparison were too small after age twenty-five and traditional levels of significance were not achieved in any of the comparisons.

\section{MULTIVARIATE RESULTS}

\section{$\underline{\text { Education }}$}

Two dependent variables were used to examine whether teenage paternity is related to educational outcomes after controlling for other variables that are presumed to affect educational attainment. The first dependent variable was the number of years of schooling completed by the 
TABLE 5

Average Income of Males at Various Ages

\begin{tabular}{|c|c|c|c|c|c|c|c|c|}
\hline \multirow[b]{2}{*}{ Age } & \multicolumn{2}{|c|}{ All } & \multicolumn{2}{|c|}{ Whites } & \multicolumn{2}{|c|}{ Blacks } & \multicolumn{2}{|c|}{ Others } \\
\hline & $\begin{array}{l}\text { Teen } \\
\text { Fathers }\end{array}$ & $\begin{array}{l}\text { Not Teen } \\
\text { Fathers }\end{array}$ & $\begin{array}{l}\text { Teen } \\
\text { Fathers }\end{array}$ & $\begin{array}{l}\text { Not Teen } \\
\text { Fathers }\end{array}$ & $\begin{array}{l}\text { Teen } \\
\text { Fathers }\end{array}$ & $\begin{array}{l}\text { Not Teen } \\
\text { Fathers }\end{array}$ & $\begin{array}{l}\text { Teen } \\
\text { Fathers }\end{array}$ & $\begin{array}{l}\text { Not Teen } \\
\text { Fathers }\end{array}$ \\
\hline 18 & $\begin{array}{l}6,573 * * * * \\
(489)\end{array}$ & $\begin{array}{l}4,922 * * * * \\
(3950)\end{array}$ & $\begin{array}{l}8,344 * * * * \\
(253)\end{array}$ & $\begin{array}{l}5,596 * * * * \\
(2763)\end{array}$ & $\begin{array}{l}4,655 * * * * \\
(193)\end{array}$ & $\begin{array}{l}3,011 \text { **** } \\
(963)\end{array}$ & $\begin{array}{l}4,768 \\
(41)\end{array}$ & $\begin{array}{l}4,873 \\
(201)\end{array}$ \\
\hline 19 & $\begin{array}{l}7,824 * * * * * \\
(567)\end{array}$ & $\begin{array}{l}6,150^{* * * * *} \\
(4668)\end{array}$ & $\begin{array}{l}9,944 * * * * \\
(299)\end{array}$ & $\begin{array}{l}6,764 * * * * \\
(3284)\end{array}$ & $\begin{array}{l}5,363^{* *} \\
(223)\end{array}$ & $\begin{array}{l}4,360^{* *} \\
(1114)\end{array}$ & $\begin{array}{l}6,141 \\
(42)\end{array}$ & $\begin{array}{l}5,983 \\
(245)\end{array}$ \\
\hline 20 & $\begin{array}{l}8,358^{* * * *} \\
(641)\end{array}$ & $\begin{array}{l}7,208^{* * *} \\
(5397)\end{array}$ & $\begin{array}{l}9,998 * * * * \\
(339)\end{array}$ & $\begin{array}{l}7,825^{* * * * *} \\
(3813)\end{array}$ & $\begin{array}{l}6,194 \\
(251)\end{array}$ & $\begin{array}{l}5,471 \\
(1265)\end{array}$ & $\begin{array}{l}7,946 \\
(47)\end{array}$ & $\begin{array}{l}6,781 \\
(291)\end{array}$ \\
\hline 21 & $\begin{array}{l}8,982 \\
(637)\end{array}$ & $\begin{array}{l}8,629 \\
(5306)\end{array}$ & $\begin{array}{l}10,525^{* *} \\
(335)\end{array}$ & $\begin{array}{l}9,391 * * \\
(3753)\end{array}$ & $\begin{array}{l}6,932 \\
(252)\end{array}$ & $\begin{array}{l}6,431 \\
(1242)\end{array}$ & $\begin{array}{l}8,785 \\
(46)\end{array}$ & $\begin{array}{l}8,051 \\
(281)\end{array}$ \\
\hline 22 & $\begin{array}{l}9,654^{*} \\
(632)\end{array}$ & $\begin{array}{l}10,605^{*} \\
(5264)\end{array}$ & $\begin{array}{l}11,274 \\
(332)\end{array}$ & $\begin{array}{l}11,589 \\
(3738)\end{array}$ & $\begin{array}{l}7,597 \\
(251)\end{array}$ & $\begin{array}{l}7,726 \\
(1219)\end{array}$ & $\begin{array}{l}9,254 \\
(46)\end{array}$ & $\begin{array}{l}9,772 \\
(278)\end{array}$ \\
\hline 23 & $\begin{array}{l}11,012 * * \\
(558)\end{array}$ & $\begin{array}{l}12,564^{* *} \\
(4582)\end{array}$ & $\begin{array}{l}12,605 \\
(297)\end{array}$ & $\begin{array}{l}13,640 \\
(3257)\end{array}$ & $\begin{array}{l}9,131 \\
(218)\end{array}$ & $\begin{array}{l}9,280 \\
(1064)\end{array}$ & $\begin{array}{l}9,354 \\
(41)\end{array}$ & $\begin{array}{l}11,823 \\
(239)\end{array}$ \\
\hline 24 & $\begin{array}{l}11,799 * * * * \\
(457)\end{array}$ & $\begin{array}{l}13,981 \text { **** } \\
(3779)\end{array}$ & $\begin{array}{l}13,609 * \\
(236)\end{array}$ & $\begin{array}{l}15,076 * \\
(2694)\end{array}$ & $\begin{array}{l}9,541 \\
(192)\end{array}$ & $\begin{array}{l}10,680 \\
(865)\end{array}$ & $\begin{array}{l}11,740 \\
(27)\end{array}$ & $\begin{array}{l}12,977 \\
(200)\end{array}$ \\
\hline 25 & $\begin{array}{l}12,331 * * * * \\
(356)\end{array}$ & $\begin{array}{l}15,608 * * * * \\
(2964)\end{array}$ & $\begin{array}{l}14,200 * * * \\
(184)\end{array}$ & $\begin{array}{l}17,055^{* * *} \\
(2107)\end{array}$ & $\begin{array}{l}10,202 \\
(149)\end{array}$ & $\begin{array}{l}11,759 \\
(691)\end{array}$ & $\begin{array}{l}10,574 \\
(21)\end{array}$ & $\begin{array}{l}13,026 \\
(152)\end{array}$ \\
\hline 26 & $\begin{array}{l}14,076 * * * * \\
(248)\end{array}$ & $\begin{array}{l}17,770 \text { **** } \\
(2142)\end{array}$ & $\begin{array}{l}17,068^{*} \\
(131)\end{array}$ & $\begin{array}{l}19,488^{*} \\
(1519)\end{array}$ & $\begin{array}{l}10,549^{* *} \\
(103)\end{array}$ & $\begin{array}{l}13,258^{* *} \\
(498)\end{array}$ & -- & -- \\
\hline 27 & $\begin{array}{l}14,897 * * * \\
(168)\end{array}$ & $\begin{array}{l}19,298 * * * \\
(1535)\end{array}$ & $\begin{array}{l}18,787 \\
(90)\end{array}$ & $\begin{array}{l}20,993 \\
(1095)\end{array}$ & $\begin{array}{l}10,065^{* * *} \\
(67)\end{array}$ & $\begin{array}{l}14,194 * * * \\
(349)\end{array}$ & -- & -- \\
\hline 28 & $\begin{array}{l}12,718 * * * * \\
(92)\end{array}$ & $\begin{array}{l}20,564 * * * * \\
(993)\end{array}$ & $\begin{array}{l}14,680 * * * \\
(42)\end{array}$ & $\begin{array}{l}22,480^{* * *} \\
(705)\end{array}$ & $\begin{array}{l}10,740 * * \\
(44)\end{array}$ & $\begin{array}{l}15,146^{* * *} \\
(226)\end{array}$ & -- & -- \\
\hline 29 & $\begin{array}{l}12,340 * * * \\
(48)\end{array}$ & $\begin{array}{l}21,452 * * * \\
(491)\end{array}$ & $\begin{array}{l}15,323 * * \\
(23)\end{array}$ & $\begin{array}{l}22,937 * * \\
(356)\end{array}$ & $\begin{array}{l}8,174 * * \\
(19)\end{array}$ & $\begin{array}{l}15,384^{* *} \\
(101)\end{array}$ & -- & -- \\
\hline
\end{tabular}

Source: Author's computations based on the NLSY.

Significance levels: $* * * *=\mathrm{p}<.001, * * *=\mathrm{p}<.01, * *=\mathrm{p}<.05, *=\mathrm{p}<.10$. 
respondent by 1988. The second was whether or not the respondent had attained his high school diploma (or its equivalent) by 1988.

Because of their high correlations, several variables were incorporated into composite measures for predicting educational outcomes. For example, instead of including the education of the mother and father separately, the highest level of education attained by either parent was included in the education models. Also, rather than include the receipt of magazines, newspapers, or having a family member with a library card, the sum of the three variables was included as a single measure of the availability of cultural capital in the home at age fourteen. This measure would equal zero if neither newspapers, magazines, nor a library card were present in the household, but three if all forms of cultural enrichment were available. Black and other race dummies were included in the equations for all respondents but were obviously excluded in the equations that were estimated individually for whites and blacks. Other regressors included in the model were the age of the respondent at the 1988 interview, whether or not the respondent lived in a poverty household in the baseline survey (1979), whether or not the respondent lived in a single-parent household at age fourteen, whether or not a foreign language was spoken in the home during the respondent's childhood, and whether or not the respondent had a mental or physical handicap. The latter two variables are viewed as important factors in determining educational achievement by the National Commission on Children (1991).

The results of the model predicting the number of years of education completed by 1988 are given in Table 6. Because of the small number of observations for other races, regression results are presented only for the full sample and for whites and blacks separately. The models for all respondents, whites, and blacks are all significant. Most variables are significant, although there is some variation across the three equations in the significance of the foreign language and mental handicap variables. Family background variables as measured by the educational attainment of 
TABLE 6

Effect of Selected Variables on Number of Years of Education Completed by 1988

\begin{tabular}{|c|c|c|c|}
\hline Variable & $\begin{array}{c}\text { All } \\
\text { Parameter Estimate } \\
\text { Beta Coefficient }\end{array}$ & $\begin{array}{c}\text { White } \\
\text { Parameter Estimate } \\
\text { Beta Coefficient }\end{array}$ & $\begin{array}{c}\text { Black } \\
\text { Parameter Estimate } \\
\text { Beta Coefficient }\end{array}$ \\
\hline Intercept & $6.32 * * * *$ & $5.427 * * * *$ & $9.563 * * * *$ \\
\hline Age, 1988 & $\begin{array}{l}0.082 * * * * \\
0.071\end{array}$ & $\begin{array}{l}0.095^{* * * * *} \\
0.079\end{array}$ & $\begin{array}{l}0.022 \\
0.023\end{array}$ \\
\hline Ever a teen father & $\begin{array}{l}-1.25 * * * * \\
-0.147\end{array}$ & $\begin{array}{l}-1.484 * * * * \\
-0.146\end{array}$ & $\begin{array}{l}-0.889 * * * * \\
-0.158\end{array}$ \\
\hline $\begin{array}{l}\text { Maximum education of mother } \\
\text { or father }\end{array}$ & $\begin{array}{l}0.270 * * * * \\
0.358\end{array}$ & $\begin{array}{l}0.286^{* * * * *} \\
0.371\end{array}$ & $\begin{array}{l}0.184 * * * * \\
0.231\end{array}$ \\
\hline $\begin{array}{l}\text { Lived in a poor household, } \\
1979\end{array}$ & $\begin{array}{l}-0.306 * * * * \\
-0.049\end{array}$ & $\begin{array}{l}-0.298 * * * \\
-0.040\end{array}$ & $\begin{array}{l}-0.442 * * * * \\
-0.101\end{array}$ \\
\hline $\begin{array}{l}\text { Foreign language spoken in } \\
\text { childhood }\end{array}$ & $\begin{array}{l}0.454 * * * * \\
0.070\end{array}$ & $\begin{array}{l}0.599 * * * * \\
0.091\end{array}$ & $\begin{array}{l}-0.272 \\
-0.024\end{array}$ \\
\hline $\begin{array}{l}\text { Lived in a single-parent home } \\
\quad \text { @ age } 14\end{array}$ & $\begin{array}{l}-0.136 \\
-0.020\end{array}$ & $\begin{array}{l}-0.024 \\
-0.003\end{array}$ & $\begin{array}{l}-0.191 \\
-0.043\end{array}$ \\
\hline Mental handicap & $\begin{array}{l}-0.382 * * * \\
-0.040\end{array}$ & $\begin{array}{l}-0.406 * * * \\
-0.038\end{array}$ & $\begin{array}{l}-0.206 \\
-0.029\end{array}$ \\
\hline Physical handicap & $\begin{array}{l}-0.036 \\
-0.006\end{array}$ & $\begin{array}{l}-0.061 \\
-0.010\end{array}$ & $\begin{array}{l}-0.037 \\
-0.008\end{array}$ \\
\hline Cultural capital & $\begin{array}{l}0.498^{* * * *} \\
0.191\end{array}$ & $\begin{array}{l}0.640^{* * * * *} \\
0.220\end{array}$ & $\begin{array}{l}0.258^{* * * * *} \\
0.126\end{array}$ \\
\hline Black & $\begin{array}{l}0.188^{* *} \\
0.032\end{array}$ & -- & -- \\
\hline Other & $\begin{array}{l}-0.007 \\
-0.006\end{array}$ & -- & -- \\
\hline $\mathrm{N}$ & 4336 & 3036 & 1102 \\
\hline $\mathrm{R}$-square & .284 & .318 & .159 \\
\hline Prob $>$ F & .0001 & .0001 & .0001 \\
\hline
\end{tabular}

Source: Author's computations based on the NLSY.

Significance levels: $* * * *=\mathrm{p}<.001, * * *=\mathrm{p}<.01, * *=\mathrm{p}<.05, *=\mathrm{p}<.10$. 
parents and the availability of cultural capital in the home were consistently significant across equations. That is, homes where the parents have achieved higher levels of education and homes where reading materials are available and there is access to a library give rise to better-educated children.

Having been a teen father is a significant determinant of the educational attainment of young men in all equations. In the model for all respondents, having been a teen father implies a deficit of 1.25 years of education after controlling for personal and family characteristics. The magnitude of the educational deficit differs across the race equations, with 1.484 and 0.889 fewer years of education acquired by teen fathers of white and black races. Bivariate results for whites had indicated a 2.5 year educational deficit for teen fathers. Thus, controlling for personal and family characteristics reduced but by no means eliminated the educational deficit of teen fathers. On the other hand, the bivariate results indicated that black teen fathers attained 0.9 fewer years of education than their peers who delayed parenting. After controlling for personal and family characteristics, this result is virtually unchanged. Thus, the regression results parallel the bivariate analyses in that the differences between teen fathers and the peers who delayed parenting were greatest among whites, with smaller yet significant differences existing between black teen fathers and their peers. Regardless of whether the deficit is 1.484 years or 0.889 years, the educational disadvantages experienced by all teen fathers should not be minimized, as these deficiencies are likely to lead to fewer and less lucrative opportunities in the labor market in adulthood.

The second educational achievement measure used was whether or not the high school diploma or its equivalent had been obtained by 1988. Given the dichotomous nature of the dependent variable, a probit estimator was used. Results for the entire sample, whites, and blacks are presented in Table 7. Again the educational attainment of parents and the availability of cultural capital in the home were positive and significant predictors of high school completion in all equations. Further, 
TABLE 7

Effect of Selected Variables on the Receipt of a High School Diploma or Its Equivalent by 1988

\begin{tabular}{|c|c|c|c|}
\hline $\begin{array}{l}\text { Variable } \\
\text { Estimate }\end{array}$ & $\begin{array}{c}\text { All } \\
\text { Parameter Estimate }\end{array}$ & $\begin{array}{l}\text { White } \\
\text { Parameter Estimate }\end{array}$ & $\begin{array}{l}\text { Black } \\
\text { Parameter }\end{array}$ \\
\hline Intercept & $-0.924 * * *$ & $-1.313 * * * *$ & 0.493 \\
\hline Age, 1988 & 0.016 & $0.027 * *$ & -0.015 \\
\hline Ever a teen father & $-0.454 * * * *$ & $-0.662 * * * *$ & -0.128 \\
\hline $\begin{array}{l}\text { Maximum education of mother } \\
\text { or father }\end{array}$ & $0.094 * * * *$ & $0.095 * * * *$ & $0.073 * * * *$ \\
\hline $\begin{array}{l}\text { Lived in a poor household, } \\
1979\end{array}$ & $-0.360 * * * *$ & $-0.435 * * * *$ & $-0.308 * * * *$ \\
\hline $\begin{array}{l}\text { Foreign language spoken } \\
\text { in childhood }\end{array}$ & $0.174 * * *$ & $0.219 * * *$ & 0.227 \\
\hline $\begin{array}{l}\text { Lived in a single-parent } \\
\text { home @ age } 14\end{array}$ & $0.185 * * *$ & -0.128 & $-0.181 * *$ \\
\hline Mental handicap & -0.056 & -0.035 & -0.082 \\
\hline Physical handicap & -0.044 & -0.053 & -0.045 \\
\hline Cultural capital & $0.224 * * * *$ & $0.295 * * * *$ & $0.116^{* * *}$ \\
\hline Black & $0.237 * * * *$ & -- & -- \\
\hline Other & -0.053 & -- & -- \\
\hline $\mathrm{N}$ & 4387 & 3078 & 1101 \\
\hline Prob $>F$ & .0001 & .0001 & .0001 \\
\hline
\end{tabular}

Source: Author's computations based on the NLSY.

Significance levels: $* * * *=\mathrm{p}<.001, * * *=\mathrm{p}<.01, * *=\mathrm{p}<.05, *=\mathrm{p}<.10$ 
having lived in a poor household at age fourteen reduced the likelihood of high school completion in all equations. Surprisingly, speaking a foreign language in the home in one's childhood was positively related to high school completion in the equations for the entire sample and whites, but was insignificant in the equation for blacks. After controlling for personal and family characteristics, having fathered a child in one's teen years was a significant determinant of high school completion for the entire sample and whites but not blacks. The insignificance of teen fatherhood in the high-schoolcompletion equation for blacks contrasted with the bivariate results, which found a 6.5 percent smaller probability of completing high school.

While not reported in tabular form, a number of other educational achievement specifications were estimated. The same models as described above were estimated for very young respondents only, with similar results obtaining. A third dependent variable, the difference between actual years of school completed in 1988 and the number of years of education the respondent indicated that he wanted to complete, was also used. In these latter equations, adolescent paternity was a significant determinant of the difference between educational attainment and educational aspirations. Wider gaps between aspirations and actual achievement persisted for teen fathers even after controlling for the personal and family characteristics described above.

\section{$\underline{\text { Labor Market Outcomes }}$}

The labor market outcomes of young men were also examined. The income earned from wages and salary at each age (eighteen to twenty-eight) were compared for teen fathers and young men who deferred parenting. Also examined were the number of weeks spent out of the labor force and the number of weeks spent unemployed at each age for teen fathers and young men who were never teen fathers. A number of demographic, human capital, and labor market characteristics were controlled for in these comparisons. In addition to whether or not the young man had become a teen father by the specified age, the other demographic characteristics included in the regressions were black and other 
race dummies, whether the youth had a physical handicap, and whether or not the youth had a mental handicap. The number of years of education completed was included as a measure of human capital investment. Thus, for example, in the regression predicting income at age twenty-five, the number of years of schooling completed as of age twenty-five was included as a regressor. At each age, whether or not the young man had completed high school or obtained a GED was also included as a regressor, as a high school credential is sometimes used by employers as a method of screening job applicants. Finally, the local area unemployment rate at each age was also included as a regressor, since this has obvious implications for the employment opportunities of youths.

The results for the thirty-three regressions described above are not presented individually but are rather summarized in Figures 1 through 3. All regressions were significant at at least the .001 level, and most of the regressors were significant in the anticipated directions, with the exception of mental and physical handicaps, which were often insignificant. The coefficients and 95 percent confidence intervals of the teen father variable at each age are portrayed in the income, weeks of unemployment, and weeks out of the labor force figures. The regression coefficients are portrayed as solid lines and are bracketed by the dashed lines representing the 95 percent confidence intervals. Whenever the solid and dashed lines are simultaneously above zero in Figures 1 through 3, teen fathers either earn more, are out of the labor force more, or are unemployed significantly more weeks than their nonfather peers. When all these lines fall below zero, teen fathers either earn less, spend fewer weeks out of the labor force, or are unemployed fewer weeks than men who delay parenting until age twenty or later.

Taken together these results suggest that teen fathers initially the labor force earlier than their peers and consequently spend fewer weeks out of the labor force. Between the ages of eighteen and nineteen, teen fathers spend fewer weeks unemployed. Further, until their early twenties, teen 


\section{Differentials in Earned Income for Teenage Fathers and Nonteen Fathers}

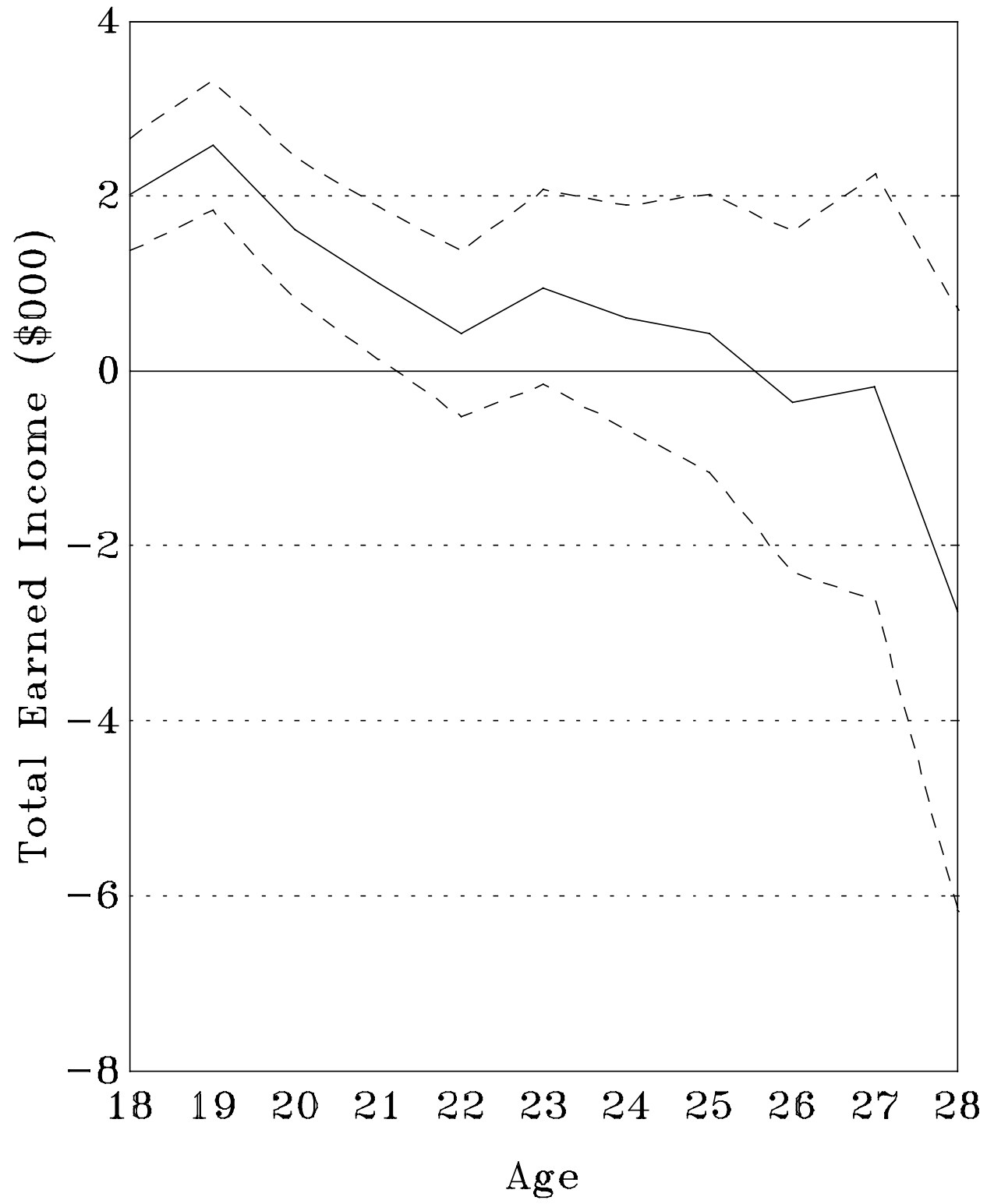


Weeks Out of Labor Force Differentials for Teenage Fathers and Nonteen Fathers

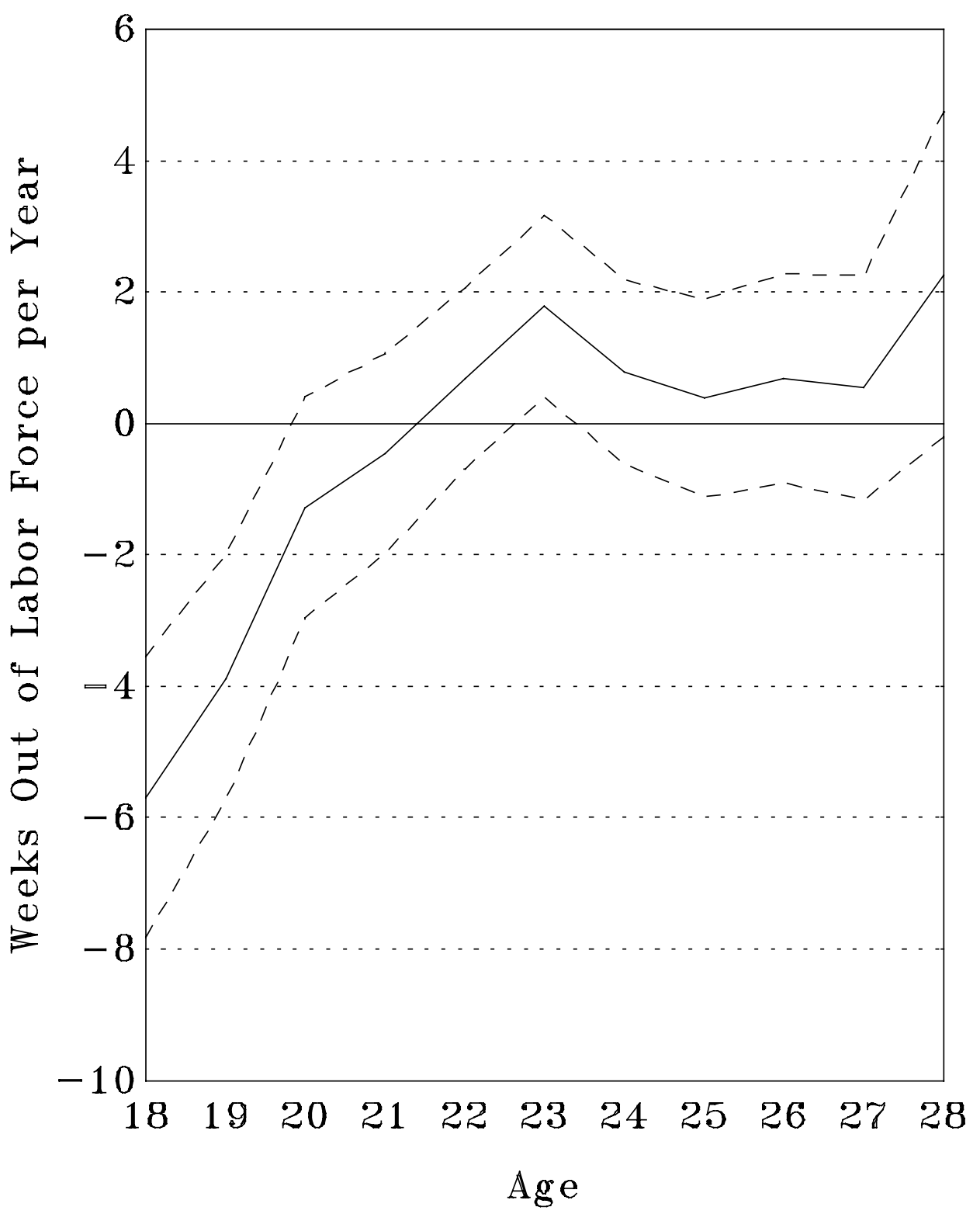




\section{Differentials in Weeks Unemployed for Teenage Fathers and Nonteen Fathers}

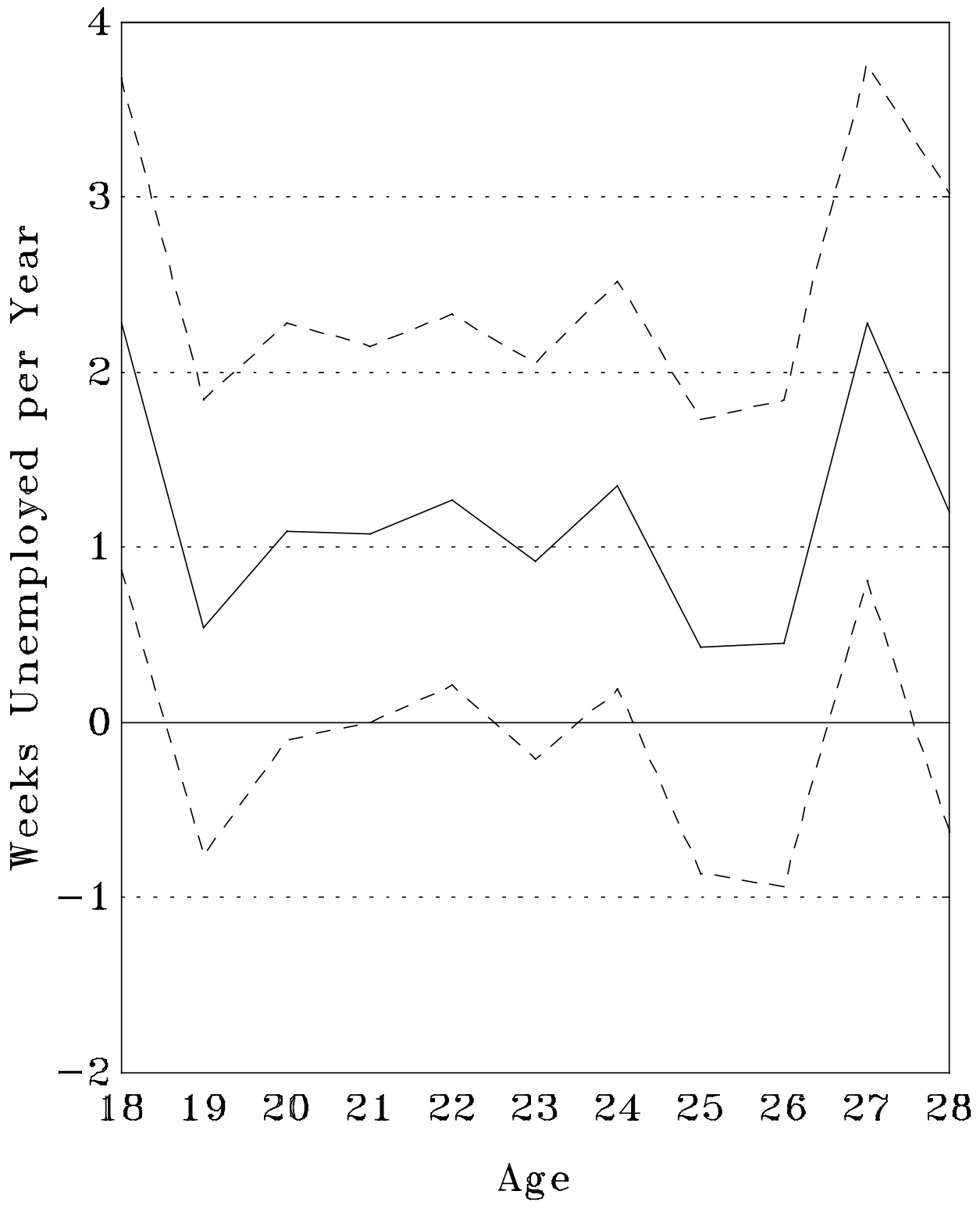


fathers earn more income than their peers. All of these patterns are fairly pronounced. On the other hand, in their mid- to late twenties, teen fathers appear to spend more weeks out of the labor force, more weeks unemployed, and tend to earn less income, although these differences are typically insignificant.

\section{SUMMARY}

Bivariate analyses reveal fairly sizable differences between teen fathers and their nonfather peers. Variables that were found to significantly differ between teen fathers and their nonfather peers for all races include the educational attainment of the respondent's mother and eldest sibling, the educational level the respondent would like to and expects to attain, the years of education completed by 1988 , and the probability of having earned a high school diploma or GED by 1988. Along each of these dimensions, teen fathers fared poorly in comparison to men who postponed having children until age twenty or later. Further, while these differences were substantial, they must be treated as lowerbound estimates of the true differences between teen fathers and their peers, given the likely underreporting of adolescent paternity in the NLSY.

A variety of additional differences existed between teen fathers and males who delayed parenting until age twenty or later among whites and/or males of "other" races. Among whites and other races, the educational attainment of the respondents' fathers was lower for teens who had children prior to age twenty. Further, among these populations, fewer homes of teen fathers had magazines or library cards available when the respondents were age fourteen. White teen fathers alone were more likely to come from impoverished households, live in a household without two parents present at age fourteen, come from a home where a foreign language was spoken during childhood, have less access to newspapers, and be less satisfied with school. 
The bivariate labor market results were somewhat more complex to describe. Overall, the work commitment of teen fathers differed only slightly from that of other young men. While teen fathers were not more willing to go on welfare if they could not support their family, they were somewhat more willing to apply for food stamps. Additionally, teen fathers were more willing than their peers to enter job training if they were unable to support their family. On the other hand, teen fathers also indicated an increased willingness to shoplift when legitimate work was unavailable. This finding is consistent with the work of other researchers who have found an increased likelihood of criminal involvement among teen fathers (Good \& Pirog-Good, 1989; Pirog-Good, 1987; Elster et al., 1987).

The bivariate labor market results suggest that teen fathers enter the labor market earlier than their peers and initially earn more income in higher-paying jobs than young men who delay parenting. However, in their early to mid-twenties, the earnings advantages disappear and eventually teen fathers earn less than young men who delay parenting. This implies that young men who delay parenting initially acquire more education; hence they enter the labor market later and do not begin to earn more than their teen father counterparts until their mid- to late twenties.

The multivariate results found that the educational deficits of teen fathers persist even after controlling for personal and family characteristics. The deficit in the years of schooling completed for white teen fathers was reduced from 2.5 years in the bivariate analyses to 1.5 years after background characteristics were controlled. On the other hand, controls for personal and family characteristics left the initial results for blacks largely unchanged, with black teen fathers completing 0.9 fewer years than blacks who delayed parenting until age twenty or later. Such was not the case, however, with the regressions estimating the impact of teen fatherhood on the probability of having received a high school diploma or completed a GED by 1988. In the regression models, the probability of having earned a high school credential by 1988 was lower for white teen fathers in comparison to other white 
males, although black teen fathers were not found to differ from their black peers along this dimension. Hence while black teen fathers complete fewer years of education than blacks who delay parenting, the difference is not sufficiently large to significantly reduce the probability of receiving a GED or high school diploma four or more years after the first birth.

Multivariate labor market results indicate that teen fathers initially earn more and spend less time out of the labor force than other young men. However, after their early twenties, these advantages are lost and teen fathers appear to spend more weeks out of the labor force and earn less than young men who delay parenting. Nevertheless, most of these deficits experienced by teen fathers never reach traditional levels of significance. Thus, the long-term earnings deficit of teen fathers does not persist after controlling for personal and family characteristics. This is a somewhat encouraging result, implying that teen fathers are as capable as other young men from similar backgrounds of providing for their children, at least throughout their twenties.

Three final points deserve mention. First, the importance of the bivariate results should not be underestimated. The bivariate results demonstrate that teen fathers acquire less education and earn less in their mid- to late twenties than other young men. The fact that some of the differences between teen fathers and other young men are diminished or eliminated after controlling for personal and family characteristics simply implies that teen fathers do only slightly worse or the same as other similarly disadvantaged males. This in no way changes the fact that teen fathers, because of their relative lack of education and worse performance in the labor force in their mid- to late twenties, may be less capable of caring for themselves as well as their children. Second, the typically smaller and sometimes insignificant differences between black teen fathers and other black males may suggest that adolescent parenting is more accepted in this population. Additionally, black households may better insulate black teen fathers from some potential adverse effects of early parenting. Alternatively, according to Mott (1985), the underreporting of births by black males was suspected to be greater than 
that of males of white or other races. Underreporting results in the erroneous classification of teen fathers as nonfathers and consequently biases downwards the estimated differences between teen fathers and other men. Hence, observable and significant differences between teen fathers and other males should be viewed as lower-bound estimates of the true differences. Because the underreporting of births is suspected to be greater among blacks, this alone might account for the less pronounced educational and labor force differences found for black teen fathers and other blacks in this study. More research on blacks is clearly warranted. Third, this is a preliminary study of the educational and labor market outcomes of teen fathers; it does not directly address the issue of causation. Consequently, I do not wish to imply that becoming a teen father causes educational or labor market deficits, but rather that these deficits simply exist among this population. For example, it is quite plausible that young men who don't like school drop out, enter the labor market early, and then decide to have a child. This scenario contrasts sharply with the notion that having a child causes young men to drop out of school in search of employment. Further causal research with this population is necessary. 


\section{Notes}

${ }^{1}$ The percentage of young men who had a high school diploma or GED by 1988 is very similar to the percentage of young men who had received their high school diploma or GED by age twenty-three. The measurement at age twenty-three is less reliable, however, as it was constructed using all survey years, resulting in fewer observations for comparison and rendering the NLSY weights used to derive national estimates in a single survey year useless. 


\section{References}

Card, J. J. 1986. "Inventory and Assessment of Data Sources on Young Male Sexuality, Contraception, and Fatherhood as Found in the Data Archive on Adolescent Pregnancy and Pregnancy Prevention (DAAPPP)." Sociometrics Corporation, Palo Alto, California, unpublished manuscript.

Chilman, C. S. 1980. "Social and Psychological Research Concerning Adolescent Childbearing: 1970-1980." Journal of Marriage and the Family 42: 793-806.

Ekstrom, R. B., M. E. Goertz, J. M. Pollack, and D. A. Rock. 1986. "Who Drops out of High School and Why? Findings from a National Study." Teacher's College Record 87(3): 356-373.

Elster, Arthur B., M. E. Lamb, and J. Tavare. 1987. "Association between Behavioral and School Problems and Fatherhood in a National Sample of Adolescent Youths." The Journal of Pediatrics 111(6): 932-936.

Fernandez, Ricardo R. and Ganagjian Shu. 1988. "School Dropouts: New Approaches to an Enduring Problem." Education and Urban Society 20(4): 363-386.

Fine, Michelle and Pearl Rosenberg. 1983. "Dropping out of High School: The Ideology of School and Work." Journal of Education 165(3): 257-272.

Finn, C. E., Jr. 1987. "The High School Dropout Puzzle." The Public Interest 87 (Spring): 3-22.

Good, David H. and Maureen A. Pirog-Good. 1989. "Models for Bivariate Count Data with an Application to Teenage Delinquency and Paternity." Sociological Methods and Research 17(4): 409-431.

Hamilton, Stephen F. 1990. Apprenticeship for Adulthood: Preparing Youth for the Future. New York: The Free Press. 
Hetherington, Mavis, Kathleen Camara, and David Featherman. 1983. "Achievement and Intellectual Functioning in One-Parent Households." In Achievement and Achievement Motives, ed. J. Spence, pp. 205-84. San Francisco: W. H. Freeman.

Hofferth, S. L. and C. D. Hayes (editors). 1987. Risking the Future: Adolescent Sexuality, Pregnancy, and Childbearing. Washington, D.C.: National Academy Press.

Lerman, Robert. 1972. "Some Determinants of Youth School Activity." Journal of Human Resources 7(3): 366-383.

Lerman, Robert. 1986. "Who Are the Young Absent Fathers?" Youth and Society 18 (September): $3-27$.

Marsiglio, William. 1987. "Adolescent Fathers in the United States: Their Initial Living Arrangements, Marital Experiences, and Educational Outcomes." Family Planning Perspectives 19: 240-251.

Miller, B. C. and K. A. Moore. 1990. "Adolescent Sexual Behavior, Pregnancy, and Parenting: Research through the 1980s." Journal of Marriage and the Family 52: 1025-1044.

Mott, Frank. 1983. "Fertility-Related Data in the 1982 National Longitudinal Surveys of Work Experience of Youth: An Evaluation of Data Quality and Some Preliminary Analytical Results." Ohio State University, unpublished manuscript.

Mott, Frank. 1985. "Evaluation of Fertility Data and Preliminary Analytical Results for the 1983 (5th round) Survey of the National Longitudinal Surveys of Work Experience of Youth." Ohio State University, unpublished manuscript.

National Center for Children in Poverty. 1990. Five Million Children: A Statistical Profile of Our Poorest Young Citizens. New York: Columbia University School of Public Health.

National Commission on Children. 1991. Beyond Rhetoric: A New American Agenda for Children and Families. Washington, D.C.: U.S. Government Printing Office. 
Olsen, Randall J. and George Farkas. 1988. "Endogenous Covariates in Duration Models and the Effect of Adolescent Childbirth on Schooling." Journal of Human Resources 24(1): 39-53.

Pirog-Good, Maureen. 1987. "Teenage Paternity, Child Support, and Crime." Social Science Quarterly 69(3): 527-546.

Pirog-Good, Maureen. 1992. "Teen Fathers and the Child Support Enforcement System." In Paternity Establishment: A Public Policy Conference. Institute for Research on Poverty Special Report 53, Vol. 2 (University of Wisconsin-Madison).

Reich, Robert. 1983. The New American Frontier. New York: Penguin Books.

Sonenstein, Freya L. 1986. "Risking Paternity: Sex and Contraception among Adolescent Males." In Adolescent Fatherhood, eds. Arthur B. Elster and Michael E. Lamb. Hillsdale, N.J.: Lawrence Erlbaum Associates.

Teti, D. M. and M. E. Lamb. 1989. "Socioeconomic and Marital Outcomes of Adolescent Marriage, Adolescent Childbirth, and Their Co-Occurrence." Journal of Marriage and the Family 51: 203-212.

Waite, L. J. and K. A. Moore. 1978. "The Impact of Early First Birth on Young Women's Educational Attainment." Social Forces 56: 845-865.

Wilson, William J. 1987. The Truly Disadvantaged. Chicago: The University of Chicago Press. 